\title{
Hygiena 3, a Forgotten Project for Electrolytic Water Treatment
}

\author{
Kryštof Drnek \\ Dept. of Economic and Social History, Charles University, Náměstí Jana Palacha 2, 11638 Praha 1, Czech Republic
}

Corresponding author: drnekk@gmail.com

\begin{abstract}
In the interwar period, the city of Prague had to resolve the problem of treating the polluted water produced by its citizens. From 1933 - 1936 an ambitious competition was held. The idea behind the competition was to bring in new ideas and projects for a new water treatment station.

Hygiena 3 was one of the projects that was submitted. It proposed a treatment procedure based on electrolytic consolidation of contaminants in water into flocks. The project was found to be inventive and interesting but too expensive and not effective. Nevertheless it was evaluated as a well developed proposal and received an award from the city.
\end{abstract}

Keywords: Hygiena 3, electrolysis, aluminum, competition, sludge.

\section{The situation in the city}

In the years between the two world wars, the capital city of Prague (also known as Greater Prague), needed to resolve the crucial problem of increasing amounts of polluted water from the increasing number of people living in the city.

The system that was in use was based on the sewer system from before the first world war, which was completed in 1906 after almost 20 years of construction works. The sewage from $88509 \mathrm{~km} 2$ of settled area wae drained to the central treatment station on Cisařský ostrov (island). There, it was filtered mechanically (i.e. the water was lead through a system of coarse racks, grid chambers and fine racks, where the primary sludge was removed, and the final treatment was done in primary clarifiers). The water treated in this way was discharged back into the river.

When the city districts were unified, the existing system was suddenly insufficient and it was predicted that the limits of the sewerage system would be exceeded 1940 (in fact, the treatment station continued in service until 1967). In the 1920s plan to move the treatment station outside the city was put forward by Ing. Eduard Máslo (1861-1926, Chief Building Advisor, a land surveyor and designer in the sanitary department). In 1929 . Máslo's plans were processed by Ing. Václav Douda (1880-?, Chief Building Advisor, from 1926 head of Construction Office 9A). The outcome was the so called "Máslo-Douda" project.

The treatment station was to be located in a new place outside the city, next to the village of Řez. Sewage was drained through several pipelines. The pipeline from the area of Vysočany and Libeň on the right side of the river, with a total length of $6406 \mathrm{~m}$ was connected to the main line on the left bank. The pipeline on the left bank was to be $6683 \mathrm{~m}$ in length and was to be connected to the new treatment station.

Again only a mechanical treatment process was planned, as in the original system, since the legal requirement was only for a mechanical system.

After the Máslo-Douda project was submitted for legal approval (the approval procedures were not completed until 1936), another project was submitted. This time, the author of the project, Ing. Eduard Zika (1879-1943, from 1922 head of the sanitary department), and his team, introduced a treatment system based on biological treatment. Zika's new sewage system was introduced in two versions - one located in the treatment station at Řež, like the Máslo-Douda project, while the other took the station back to Císařský ostrov island, because the system would be more secure and less smelly.

To adjudicate on these conceptions, and to bring in more ideas on how to deal with the problem, the city council held the General Project competition from 1933-1936.

\section{The General project}

The competition was announced on May 2nd 1933, and the deadline for applications was March 15th 1934. The competition was open only to citizens of Czechoslovakia.

A commission was nominated by the city council and comprised 17 members and 2 experts. During the standing time of the commission, 2 members died and others were nominated to replace them.

The rules of the competition set several conditions: 


\section{Irojebt : Inģ Douda-Ing Márlo}

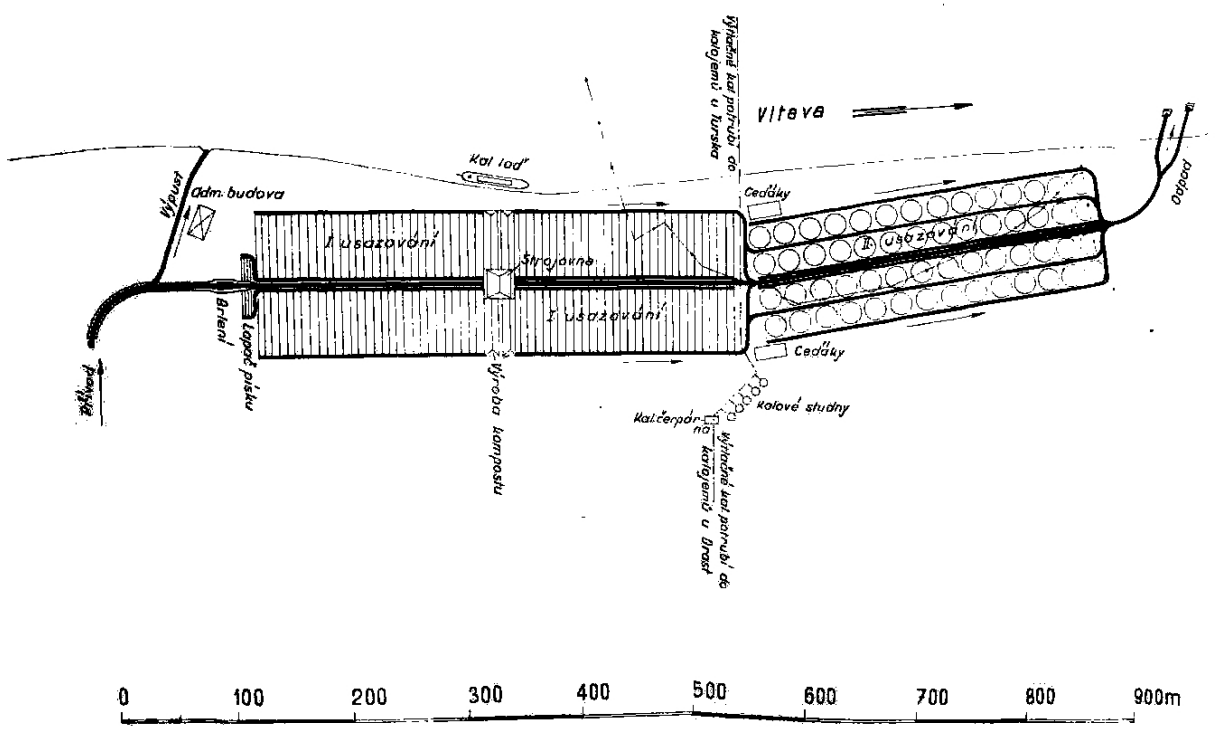

Figure 1: Picture of the original "Máslo-Douda" project.

- The average amount of sewage per day was $129 \ell$ in 1927 and $118 \ell$ in 1929. The Máslo-Douda project set an amount value of $160 \ell$ per day.

- The number of users in the period between 1940 and 1960, would rise from 1 mil. to 1.6 mil. In 1929 there were only 601000 users.

- The treated sewage should contain not more than $250 \mathrm{mg}$ of dry sludge. The sludge taken in treatment process must not decompose, sand from the sand pool must contain not more than $10 \%$ of dry residue, and the sludge from the sedimentation tank must contain not more than $91 \%$ of water.

- The location of the new sewage plant must not offend hygienics and aesthetic standards. The location could be in a populated area, but if so the hygienic measures would have to be more accurate and stricter.

- The new sewage plant was required to treat all sewage from the city.

Fifteen projects were submitted before the deadline. Finally only 13 were admitted, and 2 were rejected because they did not comply with the conditions. However, the rejected projects were so interesting that the committee also screened them.

The projects that entered the competition was divided into four groups:
1. Plants located on Císařský ostrov (island) projects Ostrov (winner of a 15 000-crown prize); Zdraví; Zdraví všem (winner of a 10000-crown prize); and Čistý vzduch.

2. Plants located near to Prague - projects Dorr (winner of the 55000-crown 1st prize); Čistá puida (winner of the 45000-crown 2nd prize); Roztoky (winner of the 20000-crown 3rd prize); and Praze ku zdaru (winner of a 15000-crown award).

3. Plants next to the river Labe — Spád and Druhá reka.

4. Special treatment programmes - Hygiena 3 (winner of a 5000-crown award); Závlaha (winner of a 10000-crown award); and Úspora (bought for 15000 crowns).

None of the projects was accepted as good enough to replace the original Máslo-Douda project and none of them was ever successfully constructed.

By the time the competition was completed, the project for a sewage plant in Rež had been licensed. The original goals of the competition, bringing in new ideas and designs for a new sewerage system for Greater Prague, were fulfilled, but they were never implemented. 


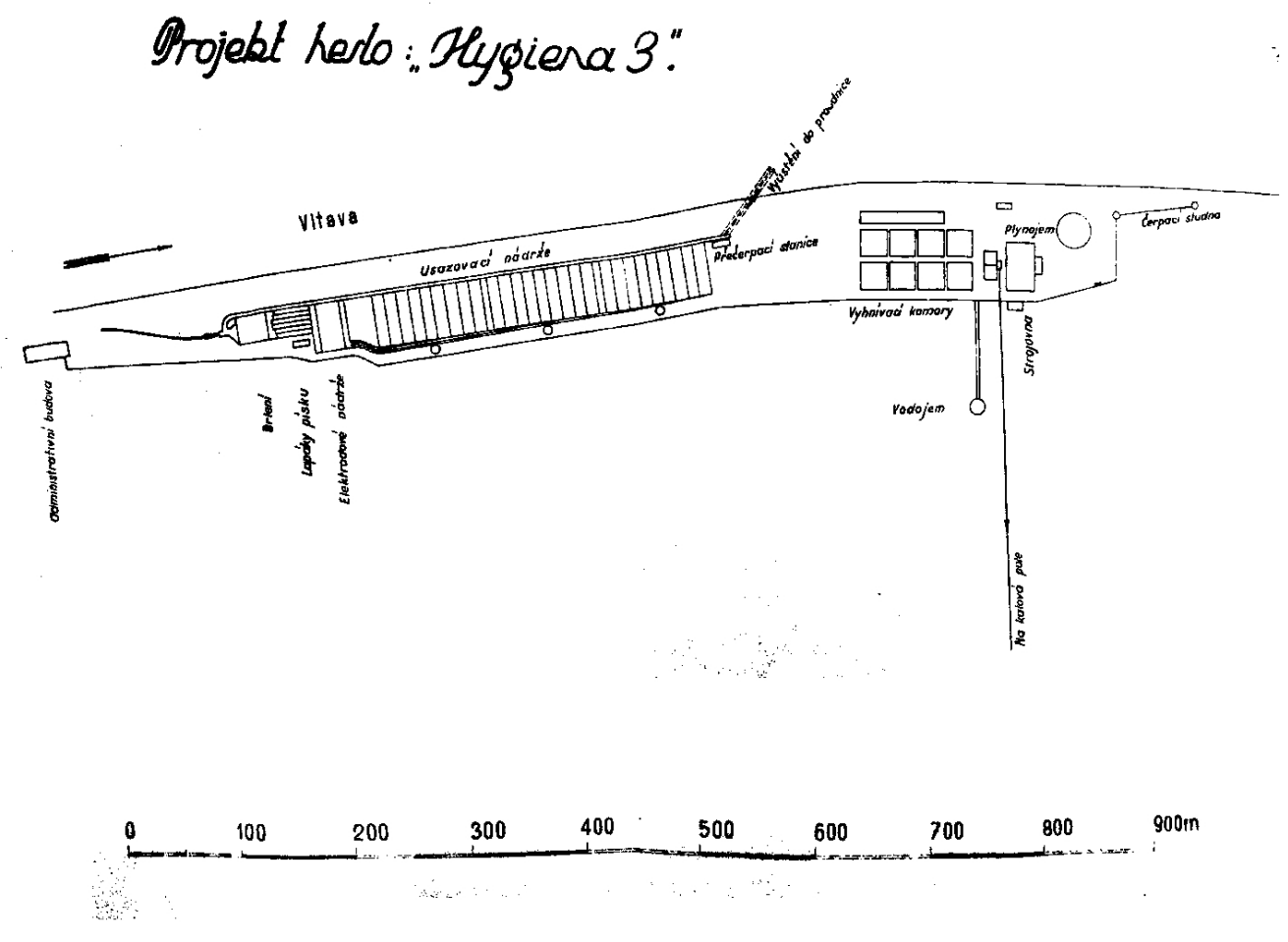

Figure 2: Map of the Hygiena 3 project

\section{Hygiena 3}

The Hygiena 3 project was one of the most innovative project proposals. Its authors were Ing.J. Roth, Ing. F. Ballasko, and Ing. Dr. J. Bulíček. The basic elements of the treatment system were mechanical. The innovative aspect, which set this project apart from the others, was the use electrolysis.

\subsection{Location}

The project located the treatment station on the edge of the city, behind Drahaňská rokle, below the quarry. The place was selected to protect the inhabitants of Prague from the smell of drying sludge. However the committee did not adjudge the location below the quarry to be an ideal place for the station, as the wind down by the river would transport the smell.

The location was able to provide enough space for expansion when the treatment plant was modernized. A wall would be built around to plant to ensure a treatment service even during a high flood. In addition, a machinery room, gasometers and administrative buildings would be built on mounds above the level of the highest known flood.

Sewage would be drawn to the station through the original pipelines, marked as IA and IB, that had been projected for the Máslo-Douda project. Due to the difference in elevation, the sewage could be drawn from the city just by gravitation.
All the buildings were planned to be constructed with shallow foundations to reduce the construction costs.

\subsection{Levels of the treatment process}

The system for the new plant was planned to have four levels - coarse and fine racks, a grid chamber, electrolysis pools, and primary clarifiers. The treated water would then be discharged back into the river, and the sludge would be discharged into sludge beds to dry out. All the machinery in the plant was described as semi-automatic, which would reduce the number of the employees and minimize the need to come into contact with contaminated water.

\subsubsection{Racks}

Active coarse and fine racks form the first level of the process, based on the example of Hamburg (the plans of the equipment used in Hamburg have been lost).

The racks have a total height of $3.5 \mathrm{~m}$, the pitch between two bars is $3 \mathrm{~cm}$, and the dimensions of the bars are $30 \times 8 \mathrm{~mm}$. The whole structure is tilted at $45^{\circ}$ to improve the collection of coarse sludge. The pollutants are collected by moving screens made into an infinite belt.

Then they are racked up by iron combs, and they are moved to the collecting baskets together with sludge from the second level of fine racks $(4.2 \mathrm{~m}$ in height, and with the same structure as the first racks). Rubber belt transporters and elevators move 


\section{LYGIENA 3}

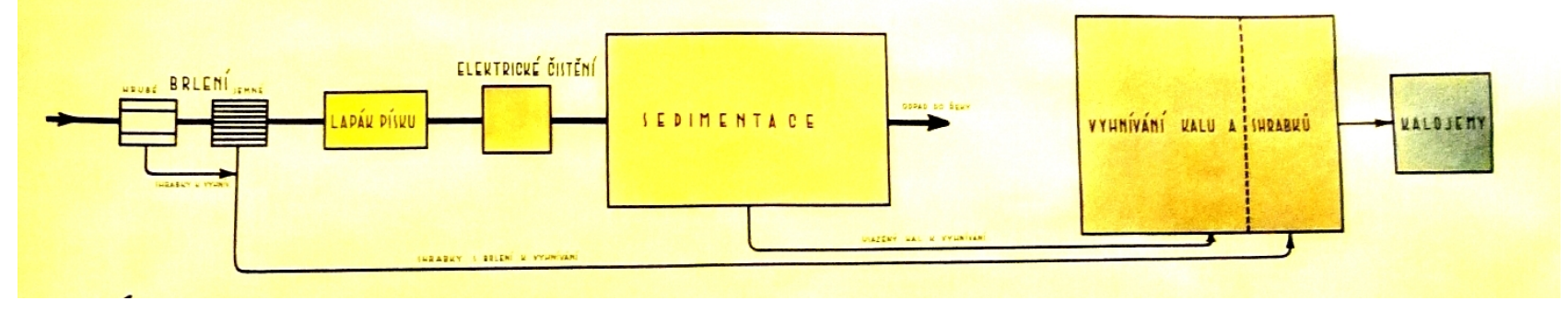

Figure 3: Schematic plan of the treatment process

the sludge through the concrete bunkers to a narrowgauge railway. The railway transports the sludge to the digester rooms. However, the report by the committee rejected the tilt and the bunkers. The tilt was considered to be too steep, and it was considered that the bunkers would have an inappropriate conical bottom, which would block the drain aperture.

All the racks are propelled by electric engines with total power of circa $5 \mathrm{~kW}$. The power needed to move the belts is circa $3 \mathrm{~kW}$.

\subsubsection{Grid chambers}

The grid chamber are operated by two mobile grabs, each of which is equipped with three sand catchers. Total power requirement for operating the machinery in the grid chamber was calculate to be $10 \mathrm{~kW}$. The sand is separated from the fine compounds by compressed air from two air compressors with $250 \mathrm{~m}^{3}$ power. The compressors were planned to be in service three hours a day. At the end of the grid chambers there is a grease trap.

The location of the grid chamber after both of the racks was considered to be problematic. The sand is mixed together with sludge from the racks and is moved to the primary clarifiers, were it would be too complicated to separate them. The system of catchers attracted criticism, as moving the whole grab was considered economically irrational.

\subsubsection{Primary clarifiers}

The primary clarifiers are a simple place, composed of several levels, for settling the sludge. The system uses Leipzig-type wipers built for $5 \mathrm{~kW}$ power. The sludge is then pushed to the collecting wells under its own pressure.

The sludge is drawn from the wells by a centrifugal pump to the digester chambers, and then by gravity to the collecting wells. Drainage takes place in the collecting wells, and after several hours the sludge is pumped through the filling station into the drying beds.

The sludge is dried in 32 chambers with a total volume of $40000 \mathrm{~m}^{3}$ for 105 days at a temperature of $27^{\circ} \mathrm{C}$. After that, the sludge is removed to the final drying beds near to the village of Brnky. The gas escaping from the sludge is collected by a gasometer, and is re-used as fuel for the engines in the plant.

\subsection{Electrolysis}

A systematic water treatment process is performed in 14 tanks with a capacity of $3000 \mathrm{~m}^{3}$, with 13 batteries in each tank. Each battery contains a system of aluminum electrodes. There are a total of 27600 electrodes, each of which is a deskboard $2 \times 1 \mathrm{~m}$ in dimensions, and the distance between them is $1 \mathrm{~cm}$.

Each deskboard is developed to convert AC to DC. The direct current operates on the flowing water for a period of $90 \mathrm{~s}$. The fine sludge in the water condenses into large, dense flakes, which are transported into the primary clarifiers for final settlement.

The condensation process had not been finalized at time when the competition closed, and it was still open to question, though it was in use in several water treatment plants in USA and Germany (no more precise specification was mentioned in the sources). In the plans, metal from the electrodes passes to the water in the form of ions, and immediately makes the colloids consolidate into insoluble hydroxide, which, after degassing, sinks to bottom of the tanks together with the sludge.

Electrolysis consumes a certain amount of aluminum to condense the sludge. The calculated amount was $1-3 \mathrm{~g}$ of aluminum per $1 \mathrm{~m}^{3}$ of sludge. With an average amount of $24000 \mathrm{~m}^{3}$ of sludge per 11 hours (the process was planned to operate only between 9 a.m. and 8 p.m.), the total amount of aluminum consumed would be $769 \mathrm{~kg}$ per day, or, more likely, $1 \mathrm{t}$ per day.

Although this system was considered extraordinarily interesting, it would have been be very problematic to implement. Major considerations were the prices of aluminum and electric power. The committee calculated that one tonne of aluminum per day would cost 18000-20000 crowns (depending on the current price for aluminum). The power consumption would be $1300 \mathrm{~kW}$ per day. Unfortunately, the main power consumption would be in the daytime 
peak period, when electricity is at its most expensive.

Last but not least, there was the problem of electrolytic water treatment. Electrolysis removes only the sludge, and microscopic bacteria and putrid germs are left untouched. Several reports concluded that this water treatment method was appropriate mainly for industrial wastewaters, because of their high impurity concentration. Urban sewage is too sparse to justify this form of treatment.

\subsection{Conclusion}

After the end of the competition, the committee decided to construct the original Máslo-Douda project, even though the city of Prague bought or made awards to six projects, including the Hygiena 3 project. None of the projects, not even the MásloDouda project, was ever constructed.

The strong point of the Hygiena 3 project was considered to be the innovative introduction of the electrolytic treatment system. However, as was pointed out above, electrolysis was found not to be effective, though there was some possibility that it could be improved. The project itself, the plans for the machinery, and almost all of the calculations, were considered to be well performed, and as a result the authors received an award of 5000 crowns.

Then the project was then filed away and forgotten, like the other plans.

\section{Acknowledgements}

The research presented in this paper was supervised by Prof.I. Jakubec, Faculty of Arts, Charles University in Prague and was supported by research programme No. 263101 "Man in the perspective of historical science".

\section{References}

[1] K. Drnek. Prague's sewerage system in the 1930' and general sewerage project (1933-1936). Acta Polytechnica. Journal of advanced engineering 50(4):22-28, 2010.

[2] T. Keclík. The competition on a general project for new sewage plants for the capital city Prague. Gas, water and sanitation engineering 16(4):1-3, 1936.

[3] Prague Waterworks fund. Archive of Prague's Waterworks and Sewerage (APVK). Panels 11611165.

[4] F. Schulz. Report on the conclusion of the competition. Gas, water and sanitation engineering 16(4):3-5, 1936.

[5] F. Topinka. Brief survey about the projects. Gas, water and sanitation engineering. Gas, water and sanitation engineering 16(4):7-16, 1936.

[6] B. Vondráček. Brief survey about the general conclusion of the committee, accredited to judge projects in the competition for new sewage plants for the capital city of Prague. Bulletin of the Capital city of Prague 42(25):517-520, 1935. 